\title{
The Implementation of Development Policy for The New School Unit of SMP Negeri 20 Singkawang
}

\author{
Asep Wahyudin ${ }^{1)}$, Maswardi.M.Amin ${ }^{2)}$, Sukmawati ${ }^{3)}$ \\ ${ }^{1)}$ Universitas Tanjungpura, Pontianak, Indonesia \\ E-mail: asepkomandan@ymail.com \\ ${ }^{2)}$ Universitas Tanjungpura, Pontianak, Indonesia \\ E-mail: maswardi.mamin@gmail.com \\ ${ }^{3)}$ Universitas Tanjungpura, Pontianak, Indonesia \\ E-mail: sukmawati@fkip.untan.ac.id
}

\begin{abstract}
The purpose of this study was to explore, analyze and reveal the process of implementing local government policies in the effort to fulfill the infrastructure of the New School Unit of Junior High School in Singkawang City. The approach used in this study is qualitative with the type of descriptive research in the form of case studies. Planning the Planning Process of the Development Policy Implementation of the New School Unit of SMP Negeri 20 Singkawang is carried out by the agency and the school. The agency makes technical instructions for implementing new student admissions that refer to ministerial regulations. The involvement of various parties and the availability of supporting data is needed in the planning process of Singkawang Junior High School New School Unit Development. The results obtained from this study are (1) Planning of the Planning Process of the Development Policy Implementation of the New School Unit of SMP Negeri 20 Singkawang carried out by the agency and the school; (2) The Implementation of Development Policy for the New School Unit of SMP Negeri 20 Singkawang is carried out in accordance with the existing technical guidelines; (3) The role of stakeholders in the implementation of local government policies in the effort to fulfill the infrastructure of the SMP Negeri 20 Singkawang New School Unit in Singkawang City, in accordance with the respective authorities and abilities; (4) Evaluation is carried out to see which stages or parts still need improvement.
\end{abstract}

Keywords: Implementation; Development; Policy

\section{INTRODUCTION}

Education is an aspect that greatly determines the progress of a nation. With better education, it is hoped that the life of the nation in the future will also be better. The world of education is not entirely without problems, the problem faced by the world of education in Indonesia is not only caused by the aspect of education itself but also related to other aspects. Some certain areas are still many schoolage children who have not yet had the opportunity to receive education at school. Especially in areas that are scattered, isolated and isolated, many elementary school graduates who do not continue to junior high school due to the economic conditions of the family are lacking, the distance to school is far and there is no public transportation.

One way that can be done in areas with the characteristics as mentioned above is to bring the school closer to the concentration of children who have not received education services. With the existence of this school, it is expected that children will be more motivated to continue their studies, by not increasing the family's financial burden and can succeed in the nine-year compulsory education program and the most important is beneficial for their lives.

The construction of the New School Unit of SMP Negeri 20 Singkawang must be supported by the provision of educational facilities and infrastructure which is an important support for achieving a goal of education. In addition, school facilities and infrastructure are one component of the school system. Each education unit is obliged to have facilities which include furniture, educational equipment, educational media, books and other learning resources, consumables, and other equipment needed to support an orderly and sustainable learning process. Each education unit is required to have infrastructure that includes land, classrooms, leadership unit 
of education unit, educator room, administration room, library room, laboratory room, workshop room, production unit room, canteen room, power installation and services, gym. place of worship, playground, creative place, and other space/place needed to support an orderly and sustainable learning process.

The basis for determining the adequacy of standards for school facilities and infrastructure is based on the Minister of National Education Regulation No. 24 of 2007 by providing a minimum of 3 classrooms with a ratio of 2 $\mathrm{m} 2$ of land area/students, leadership room, teacher room, administration room, library room, science laboratory room, room UKS, BP, student/teacher bathroom/WC, playground /sports (according to SPM) with a minimum land area of $2,170 \mathrm{~m} 2$ for building 1 st floor (grant/endowments and/or buying) on behalf of the school foundation/organizer or land tenure and school building infrastructure for a period of at least 20 years and proof of ownership of educational facilities.

The policy of the Singkawang city government to hold the New School Unit of SMP Negeri 20 Singkawang in Singkawang City is based on the low gross enrollment rate (APK) at the education level, especially junior high schools in Singkawang City. Rough Participation Rate (APK), shows the participation of the population who are studying according to their level of education. Rough Participation Rate (APK) is the percentage of the population who are attending school at an educational level (regardless of age) to the number of school-age population that matches the level of education.

APK is used to measure the success of educational development programs held in order to expand opportunities for residents to receive education. APK is the simplest indicator to measure the absorption capacity of the schoolage population in each level of education. The APK value can be more than $100 \%$. This is because the population of students who attend school at an education level includes children aged outside the school age at the relevant education level. For example, many children aged over 12 years, but still in elementary school or many children who are not yet 7 years old but have entered elementary school.

The existence of students older than the standard age at a certain level of education shows the occurrence of cases of living in class or being late for school. Conversely, students who are younger than the standard age who sit at an educational level indicate that students enter school at a younger age. APK SMP Calculation Formulas $=\{($ Number of residents who attend junior high school The population is 13-1515 years old) X 100\}

Based on data from the Department of Education and Culture of Singkawang City in 2018 APK at the junior high school level in 2007/2008 was $0.63 \%$. Although in the following year there was a percentage of fluctuation but compared to $2008 / 2009$ it was $4.60 \%$, there was an increase in the Gross Participation Rate (APK). In the data sourced from the West Kalimantan Central Bureau of Statistics, the APK at the junior high school level in Singkawang City from 2010 was $59.02 \%$. Even though in the following year there was a percentage fluctuation but compared to 2010 there was an increase in the Gross Participation Rate (APK).

From the results of preliminary observations, it is known that the Development of the New School Unit of Junior High School in Singkawang City shows optimal results in increasing the Gross Participation Rate (APK). The community (students) feel very helped by access to education through the construction of a new school unit. For parents, their children do not have to travel long distances to go to school with the same quality of education as other schools. This is one of the reasons why researchers conduct research on the construction of the New School Unit of SMP Negeri 20 Singkawang in Singkawang City.

Another consideration is the construction of the New School Unit of SMP Negeri 20 Singkawang in Singkawang City and the management is running well and has a positive response from the community. Based on the description above, the researchers followed up with plans to conduct a research entitled "IMPLEMENTATION OF DEVELOPMENT POLICY FOR THE NEW SCHOOL UNIT OF SMP NEGERI 20 SINGKAWANG".

\section{RESEARCH METHOD}

This study intends to reveal holistically, deeply with its complexity. Therefore a relevant approach is qualitative research. This research uses descriptive research in the form of case studies with a qualitative approach because the data to be obtained is not in the form of numbers but in the form of field notes and interviews. This aims to explain and narrate the development policy of the new school unit of SMP Negeri 20 Singkawang.

\section{RESULT AND DISCUSSION}

\section{A. Result}

Based on the data above, the researcher obtained several findings from the research related to the Development Policy Unit of the New School Unit of SMP Negeri 20 Singkawang in Singkawang City. Based on the research findings the implementation of this activity can be carried out properly because (1) the involvement of various parties and the availability of supporting data, is needed in the planning process of the Development of the New School School Unit of SMP Negeri 20 Singkawang in areas with isolated, remote and scattered criteria, that the implementation of New School Unit Development of SMP Negeri 20 Singkawang is carried out because it looks at the needs of the community, followed up with planning, beginning with the making of proposals by involving and supporting various parties. A plan will not be in vain if it suits the needs of the community where many elementary school children do not continue until junior high school; (2) The right target socialization process facilitates the acquisition of support and can increase public awareness that socialization is carried out in various ways and by authorized parties so that the community understands and participates. The realization of the socialization activities helped the community to build schools, the community members were 
aware of the importance of education and students had the spirit of learning; (3) The implementation process, as good as any planned policy, if it is not implemented is useless. On the contrary, as simple as any of the policies, if it has been implemented it becomes useful. The availability of various components of the education system and the harmony of work relations accelerates and improves the achievement of educational quality. Four local characteristics that influence policy implementation: regional conditions, community, school principals and teachers (4) The role of stakeholders according to their respective authorities and abilities is very meaningful for improving school performance. Without their involvement, the development program of the New School Unit of SMP Negeri 20 Singkawang cannot be carried out properly, both in the development process and in the learning process. Each element of stakeholders (parents of students, communities, committees, Principals, and Heads of City Education and Culture) has roles in accordance with their existence. All support each other for the implementation of the New School Unit Development Program in SMP Negeri 20 Singkawang.

Planning the establishment of the Construction of the New School Unit of SMP Negeri 20 Singkawang based on the new education policy in the framework of completing the 9-year compulsory education that is intended for graduates of SD/MI who do not / have not been accommodated. The plan for the establishment of the Construction of the New School Unit of SMP Negeri 20 Singkawang is based on the reality in the community that is geographically far from the public school, while they are in dire need of education for their children. Planning is carried out based on the needs of the community (social demand approach) so that the program that is run gets support from the community because it is useful. The activity of planning the establishment of the Construction of the New School Unit of SMP Negeri 20 Singkawang begins with making a proposal that is equipped with supporting data. Planning and making proposals for the Construction of the New School Unit in SMP Negeri 20 Singkawang is carried out by the Principal as many parties know the condition of students, schools and the surrounding community assisted by the teachers. As for the planning process by submitting a proposal, then there is verification of eligibility and announcement.

The implementation of the policy for the Development of the New Serkolah Unit of SMP Negeri 20 Singkawang can be implemented because of the support from various parties. Togetherness between all components is realized in several forms, including the principal in carrying out the tasks assisted by the vice principal and the teacher council. While the togetherness of the junior high school with the government, and the City government provides land for the establishment of schools. The availability of students, teachers as educators, and infrastructure has fulfilled the requirements for school administration.

The role of stakeholders (parents of students, communities around the school, students, teachers, principals, and the Head of Primary and Secondary
Education Office of City Education and Culture) in education can be realized in various forms, in accordance with their respective authorities and abilities. The involvement of stakeholders can be tangible; energy, ideas, and matter. Awareness of sending children to school is also a form of community participation. The involvement and existence of students are very necessary for the implementation and sustainability of the New School of SMP Negeri 20 Singkawang.

From planning to implementing a program, a comprehensive evaluation must be carried out, as well as in the New School Unit Development of SMP Negeri 20 Singkawang. There are several things that are noted, namely the lack of learning support facilities including computers, library books, and teaching staff that are still lacking for certain subjects. The narrow access of the Gang Tak Sangka road needs to be paid attention to be widened so that then the vehicle does not experience obstacles.

B. Discussion

Based on the findings of the study, researchers discussed and presented the results of research on the Implementation of Development Policy for the New School Unit of SMP Negeri 20 Singkawang from planning, implementing, the role of stakeholders and evaluation. The data is obtained from interviews and documentation studies. The results of the research can be described as follows:

1. Policy Planning Process of the Regional Government of Singkawang City for the procurement of the New School Unit of SMP Negeri 20 Singkawang.

Planning the establishment of the New School Unit of SMP Negeri 20 Singkawang in Singkawang City based on education policy in order to complete 9-year compulsory education for graduates who are not / have not been accommodated because they are outside the reach of public schools. The policy of the Singkawang city government to hold the New School Unit of Junior High School in Singkawang City is also based on the low gross enrollment rate (APK) at the education level, especially in junior high schools in Singkawang City.

This School Unit of SMP Negeri 20 Singkawang in Singkawang is based on the reality in a geographic area that is not accessible from junior high schools, while they are in dire need of education for their children. Planning is carried out based on the needs of the community (social demand approach) so that the program that is run gets support from the community because it is useful.

Opinions about the importance of planning are also put forward by Anderson and Bowman 1964 (in Sutisna 1989: 192), planning is the process of preparing a set of decisions for future actions. This definition suggests that planning leads to and includes making decisions. Decision making is often an important part of planning. It is a process in which a complete action program is prepared in advance before each part is carried out through specific decisions. This is reinforced by Sagala (2002: 46) states that planning includes activities to determine what you want to achieve, how to 
achieve it, how long, how many people are needed, and how much it will cost.

The activity of planning the establishment of the New School Unit of SMP Negeri 20 Singkawang in Singkawang City begins with making a proposal that is equipped with supporting data. Planning and making proposals for the New School Unit of SMP Negeri 20 Singkawang is carried out by the Principal as many parties are aware of the condition of students, schools and the surrounding community assisted by the teachers. As for the planning process by submitting a proposal, then there is verification of eligibility and announcement.

To get positive support from the residents of the surrounding community, the school principal carries out socialization. The socialization is carried out by the school principal so that the community understands and participates. The authorities authorized the New School Unit of Junior High School in Singkawang mainly as principals by inviting meetings of community leaders (village officials, teachers, principals and other community leaders); socialization was carried out in stages, from the community leaders to the people of the surrounding community. The target of socialization is all citizens, especially parents of students and students; the result of the socialization activity was the growth of public awareness in education and the existence of the New School Unit of SMP Negeri 20 Singkawang in Singkawang reducing unemployment.

The role of stakeholders (parents of students, communities around the school, students, teachers, principals, and Head of Basic Education Section of the District Education Office) in education can be realized in various forms, in accordance with their respective authorities and abilities. Involvement of stakeholders can be tangible; energy, ideas, and matter. Awareness of sending children to school is also a form of community participation. The involvement and existence of students are very necessary for the implementation and sustainability of the school.

2. The process of implementing the policy in an effort to fulfill the infrastructure of the New School Unit of SMP Negeri 20 Singkawang in Singkawang City

To get positive support from the residents of the surrounding community, in order to implement this program, the school principal conducts socialization. The socialization is carried out by the school principal so that the community understands and participates. The authorities authorized the New School Unit of SMP Negeri 20 Singkawang policy in Singkawang City mainly as principals by inviting meetings of community leaders (village officials, teachers, principals and other community leaders); socialization was carried out in stages, from the community leaders to the people of the surrounding community. The target of socialization is all citizens, especially parents of students and students; the result of the socialization activity was the growth of public awareness in education and the existence of the
New School Unit of SMP Negeri 20 Singkawang in Singkawang reducing unemployment.

The policy implementation of School Unit of SMP Negeri 20 Singkawang can be implemented because of the support from various parties. Togetherness between stakeholders can be realized in several forms, including the principal in carrying out the task assisted by the vice principal and vice head of junior high school. While the togetherness of the junior high school with the government in the construction of school buildings, and the city government provides land for the establishment of schools. The availability of students, teachers as educators, and infrastructure has fulfilled the requirements for school administration.

Actuating terms, there are some experts who call it the term 'directing'. This is in line with Terry's opinion (in Usman Husaini 2014: 172), directing is actuating is getting all members of the group to want to be directed to the objective of being willing with the managerial planning and organizing efforts. Therefore actuating is actually an action, because something will not happen if there is no action.

With regard to the series of activities to develop the New School Unit of SMP Negeri 20 Singkawang, relevant parties namely the Education and Culture Office issued a Decree of the Head of the Singkawang City Education and Culture Office Number: 79 of 2012 concerning the Establishment of the School Unit Development Committee of SMP Negeri 20 Singkawang it contains that in order to complete the 9-year Compulsory Basic Education Program, the government has implemented the Block Grant Program for the Development of New School Units (USB through the Directorate of Junior Development, Directorate General of Primary Education, Ministry of Education and Culture.

3. The Role of Stakeholders in Local Government Policy Implementation in the effort to fulfill the infrastructure of the New School Unit of SMP Negeri 20 Singkawang in Singkawang City

The role of stakeholders (parents of students, the community around the school, students, teachers, principals, and the Head of the Primary and Secondary Education Division of the Singkawang City Education Office) in education can be realized in various forms, in accordance with their respective authorities and abilities. The involvement of stakeholders can be tangible; energy, ideas, and matter. Awareness of sending children to school is also a form of community participation. The involvement and existence of students are very necessary for the implementation and sustainability of the school.

The Education and Committee Board of SMP Negeri 20 Singkawang as a manifestation of the voice of the community is quite solid in garnering positive perceptions in the framework of implementing the construction of the New School Unit of SMP Negeri 20 Singkawang. Communication between the school and the education council and school committee is very high so 
that the problems that arise as small as possible can be solved properly. In the Ministry of National Education it is stated that the roles that must be carried out by the Education Council and School Committee are (1) as an advisory agency, (2) supporting agency (supporting education service activities), (3) controlling agency (controlling education service activities), and (4) mediator or liaison or liaison between the community and the government.

To be able to empower and enhance the role of the community, schools must be able to foster collaboration with parents and the community, creating a conducive and pleasant atmosphere for students and school residents. That is why the MBS paradigm contains meaning as participatory management which involves community participation, so that all policies and decisions taken are joint policies and decisions, to achieve mutual success.

The role and stakeholders in the construction of the New School Unit of SMP Negeri 20 Singkawang were stated in the Minutes of Collection of Candidates for the New School Unit of SMP Negeri 20 Singkawang Construction in 2012. After the voting series was completed, the Minutes of New School Unit Development Committee was issued. SMP Negeri 20 Singkawang with Number: 420/43 / SMPN 20/2012.

The role and stakeholders in the construction of the New School Unit of SMP Negeri 20 Singkawang were also stated with the Minutes of Collaboration of Technical Team Candidates for the Construction of the New School Unit of SMP Negeri 20 Singkawang with the same number: 420/43 / SMPN 20/2012.

4. Evaluation of the implementation of the implementation of the New School Unit of SMP Negeri 20 Singkawang Development Policy

There are several things that become an important note, namely the lack of learning support facilities including computers, library books and lack of teaching staff for certain subjects. The narrow access of the Gang Tak Sangka road needs to be paid attention to be widened so that then the vehicle does not experience obstacles.

The structure and quality of the building itself are quite representative and complete because the standards are determined based on technical guidelines from Australia. The building is equipped for people with disabilities despite the fact that there are no students with disabilities in the field.

\section{CONCLUSIONS AND SUGGESTIONS}

A. Conclusions

Based on the results of the research and the discussion presented, it can be concluded as follows:

1. Planning the Planning Process of the Development Policy Implementation of the New School Unit of SMP Negeri 20 Singkawang is carried out by the agency and the school. The agency makes technical instructions for implementing new student admissions that refer to ministerial regulations. The involvement of various parties and the availability of supporting data is needed in the planning process of the New School Unit of SMP Negeri 20 Singkawang Development.

2. Implementation of Development Policy of the New School Unit of SMP Negeri 20 Singkawang is carried out in accordance with the existing technical guidelines. The stages begin with the issuance of a Decree of the Head of the Singkawang City Education and Culture Office Number: 79 of 2012 concerning the Establishment of the New School Public Unit (USB) Construction of SMP Negeri 20 Singkawang, in which it contains Program Block Grant for the Development of New School Units (USB through the Directorate of Junior High School Development, Directorate General of Primary Education, Ministry of Education and Culture.

3. The role of stakeholders in the implementation of local government policies in the effort to fulfill the infrastructure of the New School Unit of SMP Negeri 20 Singkawang in Singkawang City, in accordance with their respective authorities and abilities is very meaningful in supporting the achievement of the program.

4. Evaluation is carried out to see which stages or parts still need improvement. From planning to implementing a program, a comprehensive evaluation must be carried out, as well as in the New School Unit of SMP Negeri 20 Singkawang Development Unit. There are several things that are noted, namely that there is still a lack of learning support facilities including computers, library books, and teaching staff that are still lacking for certain subjects. The narrow access of the Gang Tak Sangka road needs to be paid attention to be widened so that then the vehicle does not experience obstacles.

\section{B. Suggestions}

Based on these conclusions can be suggested as follows.

1. For the Principal

As the manager of Singkawang Junior High School 20 , one thing that can be used as an experience in this school development process is that it should empower, provide opportunities and or encourage all stakeholders so that they are willing, without coercion, participate optimally in order to achieve school goals, and strive for this school can continue to educate the nation's children and achieve the expected improvement in the quality of education.

2. For the teacher council

This task is very noble, educating the nation's children, especially with the creation of representative school buildings with exceptional standards, it is expected that professional teacher competencies will be realized. Teacher professionalism must be used as a guideline for all teachers in carrying out their duties because when all 
teachers are professionals in carrying out their duties, quality education will be realized.

3. For the Singkawang City Education and Culture Office

In order to be able to complete the facilities and infrastructure that are still needed by SMP Negeri 20 Singkawang so that they can compete with other schools in achieving maximum performance.

4. For the Public Works Office of Singkawang City It is necessary to improve the infrastructure where schools are located, for example improving roads leading to schools so that teachers or students are more motivated to work and study.

5. For the community around the school

It is expected to better understand the importance of basic education for their children. For this reason, their cooperation and participation is needed for sustainability and improving the quality of schools. Public education is expected not only in junior high school but can continue to a higher level, our compulsory education is not only 9 years but 12 years.

\section{REFERENCES}

Badan Pusat Statistik Kota Singkawang (2016). https:// singkawangkota. bps. go.id.

Peraturan Menteri Pendidikan Nasional Nomor 24 tahun 2007 tentang sarana dan Prasana.

Sutisna, O. 1989. Administrasi Pendidikan (Dasar Teoritis Untuk Praktek Profesional). Bandung: Angkasa.

Sagala, S. 2002. Administrasi Pendidikan Kontemporer. Bandung: Alfabeta.

Usman, H. 2014. Manajemen. Teori, Praktik, dan Riset Pendidikan. Bumi Aksara: Jakarta. 